\title{
City in Dragon Circle: Study of the History of Pagoda and Its Deployment in Manado, 1819 - 2018
}

\author{
Ivan R. B. Kaunang \\ Department of History, Faculty of Humanities, Universitas Sam Ratulangi \\ Manado, Indonesia \\ ${ }^{*}$ Corresponding author: ivankaunang67@gmail.com \\ DOI: https://doi.org/10.14710/jscl.v5i1.26021
}

Diterima/Received: 20 Oktober 2019; Direvisi/Revised: 24 Januari 2020; Disetujui/Accepted: 13 April 2020

\begin{abstract}
This article discusses the history of the pagoda formation and its distribution along with the presence of Chinese existence in Manado. This study also discusses the factors and the impact of the pagoda in Manado. The first pagoda in Manado was beginning to exist in 1819 , and in a fairly long period until 2018, the development and distribution were very slow despite the presence of Chinese in this area since the 17 th century. This study was carried out using historical methods and analysis. The data obtained were processed using a qualitative descriptive approach. The results of the study show that the presence of the pagoda together with the initial settlement of Chinese people brought by the Dutch VOC was aimed to build the fort of Fort Amsterdam. Although it impressed by the slow erection and distribution of pagodas in Manado, the causal factors and the impact are interesting in relation to interfaith, interethnic relations, urban expansion, religious space contestation, opening wider economic access and become tourism destinations.
\end{abstract}

Keywords: Urban History; Dragon Circle; History of Pagoda; Pagoda Distributing.

\section{Introduction}

The existence of Chinese ethnic in every region in Indonesia is particularly found in areas near ports, trade centers and surrounding fortifications built by the Dutch colonial. This is also related to the social status of the population in the colonial era which placed Asians higher in status than the local population. The port cities in Indonesia, in general, had villages which had been regulated by the colonial government in relation to socio-economic and security controls. These three things become important in managing the political economic stability around the fort town, as the location of Manado is related to the study of the history of the pagoda which is the subject of this work.

As a developed city, Manado is a multicultural city inhabited by residents who come from various ethnic, religious and racial backgrounds, including ethnic Chinese. The distinctiveness of the Chinese ethnic in a city is marked by the establishment of a number of pagodas which are generally located in the economic and trade center of the city of Manado. This is also the reason given the title "City Within the Dragon Circle". The location of the Ban Hin Kiong temple located at Jalan D.I Panjaitan is likened to the head of a dragon and its tail is circular protecting the city.

This study discusses the pagoda's formation and its distribution along with the presence of Chinese people in Manado. This study will also discuss the causal factors and impact of the pagoda deployment in Manado. The first pagoda in Manado began to exist in 1819, and in a fairly long period until 2018 the development and distribution were very slow despite the presence of Chinese people in this area since SpanishPortuguese times.

In historiography, the study about pagoda in Manado is limited and rare. Information on the existence of hundreds of years old pagodas and known as toapekong house were written by a former Kapitan China, Oey Pek Yong (1957). Furthermore, in the memorial book 
commemorating the birthdays of Kwan Sen Ta Tie or Kwan Kong and the inauguration of the Kwan Seng Ta Tie Manado building, on July 29, 2005 (24 Lak Gwee 2556 Lunar New Year) a book "The Meaning of Religion Behind Tradition" was published containing a glimpse of Kwan Kong Manado pagoda. Other information that also complements the story of the existence of the pagoda in Manado from newspapers and magazines that provide information on pagoda activities such as Cap Gomeh, Tapikong, Toapekong Pasiar (Fikiran, March 5, 1927), Pagoda history (Liberty, 1970) or historical events related to the burning of Ban Hin Kiong pagoda on March 14, 1974 (Gara and Pasiak, 2009).

In general, studies on pagoda are mostly studied from the architect aspect, the rest is information relating to tourism activities, prayer rituals through local newspapers, and online tourism brochures which are limited from historical aspects. One of the writings on the Ban Hin Kiong pagoda is the work of Wulanningrum (2018) which examines the variety of decoration on the uniqueness of the building, facades and the many symbols that appeal to the pagoda.

Judging from the development of pagoda in Manado, it cannot be separated from the Chinese people of Chinese citizens in Manado, who seem to be exclusive, so that data collection is often considered difficult, which makes exploration of Chinese studies also still limited. Information about Chinese citizens, from a cultural aspect to its historical aspects, seems to be relatively difficult to obtain. If there were Chinese informants who could provide information, it was still very limited due to records that were lost during the Japanese occupation (1942), the upheaval of Permesta (1957-1961), and the fire in 1974. Relation to the historical heritage of the pagoda, from the physical aspect indeed many, has been found but few generations are able to explain it. However, freelance writings in various books, magazines and newspapers also provide information on the history of the temple and the existence of Chinese descendants in Manado.

This paper attempts to reconstruct the historical setting of Chinese people who later established the pagoda as a center of worship, the cultural center of the three teachings of Tridharma.
The next discussion explains the factors that cause the distribution of temples and the impact of their distribution which become focuse of this study. The study of temples in Manado and their distribution has specifically unique because the establishment of temples in one place also opens economic access, expand geographic spatial growth of urban areas, including inter-ethnic human interaction, and between religions and adherents. According to the historical aspects of this study is still wide open to be studied from various aspects and has not yet received attention.

\section{The Arrival of Chinese People in Manado}

Long before the Chinese arrived at the location of Manado, Chinese migrants from their home country had come to Indonesia for a long time. The period of mass presence began to be felt before the colonial influence was even more apparent in the colonial era of the 19th century. Even though they had difficulty in transportation and there were restrictions and severe penalties from the emperor if they were found to leave China (Soeryadinata, 1988: 1), but in reality, the Chinese people were in many places in the archipelago, including until they could arrive in Manado via Ternate-Maluku.

The presence of the Chinese people in the Manado location was inseparable from the role of the main sea transportation routes at that time, the presence of merchant ships and sailors who sought trade relations with the areas that became the trading destinations at that time. It happened since the 16 th to 17 th centuries, when the Portuguese and Spanish period and continued until the VOC period. The $19^{\text {th }}$ century became the struggle period for the trading networks, which today are known as areas of people's ports and national ports. There are several ports in North Sulawesi, such as the port of Manado, the port of Kema, port of Bitung, port of Likupang, port of Amurang, and some other ports that are no longer developing, namely the port of Borgo-Tanawangko, ports in the Mandolang area (village of Bulo) and some on the coast East of the Minahasa to the interior of the harvesting rice location in Tondano. In the period mentioned above until the 19th century became the trajectory areas and destinations of various 
nations to trade and obtain spices (Kaunang, et al., 2016: 76-79).

Maluku is said to be the origin of traders, and of Chinese people who came to the location of Manado in the period above. Maluku represents the archipelago which has been known for a long time by Chinese people, recorded since the 15th and 16th centuries. Even long before that the clove and nutmeg trade between the China mainland with the Moluccas had occurred. The Encyclopedia van Nederlandsch Indie (1918) reports that since the 7 th century $(608-907)$ the Tang Dynasty in China, the name Maluku has been known by the term Mi-li-ki (referred to Maluku). It is said that there were gifts given by Javanese kings to the Emperor of the Sky Kingdom in the form of colorful feathers parrots. It can be ascertained that the parrots are birds with a beautiful appearance, colorful feathers and cleverly taught to speak are from Maluku. The story circulated and developed until it arrived in China which was brought by Chinese traders with a conveyance called junk or jung (Graaf, 1918: 771-772, 774).

As it is known, the cooperation agreement korte verklaring and lange verklaring was also carried out by the VOC-Dutch with the Minahasa, from here, like the sultanates of Ternate and Tidore, the initial friendship was carried out as mutual friends. On the one hand, the VOC had economic importance for the Minahasa, but on the other hand the Minahasa felt safe with Portuguese and Spanish interference from the protection of the VOC's ferocious vessels against the PortugueseSpanish interfe-rence.

The collaboration of the GovernorGeneral of the VOC, Padtbrugge with the traditional Minahasa leaders, the Walak leaders gave the VOC the freedom to transport rice from the Minahasa coast through the port of Kema and transported to Ternate-Maluku. The large number of Minahasa crops that were not only limited by rice, and the limited ability of VOC ships were not entirely capable of transporting Minahasa crops, the VOC made use of Chinese junk; Chinese ships to transport rice in Minahasa in 1607 (Molsbergen, 1928: 7; Toar, 1978: 24, 33). This has become more intense since 1824, when Manado-North Sulawesi and its surroundings were part of the Ternate residency (Staatsblad, 24 June 1824).
These Chinese junk officers were the first to be present in this area during the Portuguese period, even long before they had conducted trade relations in the archipelago, such as on Java and Sumatra (Brouwer, 1936: 1-2). Initially, they came and went according to the tasks they were assigned. Over time they brought their blood brothers to trade for a while and then stayed permanently. Especially when the Dutch VOC built lodge/Benteng in Manado, they then brought a number of workers, namely the Chinese people to this area, which over time there were group settlements based on their origin. This is the forerunner of the "Chinese Village (Kampung Cina)" in Manado. Long before the Chinese arrived at the location of Manado, Chinese migrants from their home country had come to Indonesia for a long time. The period of mass presence began to be felt before the colonial influence was even more apparent in the colonial era of the 19th century. Even though they had difficulty in transportation and there were restrictions and severe penalties from the emperor if they were found to leave China (Soeryadinata, 1988: 1), but in reality, the Chinese people were in many places in the archipelago, including in Manado. They arrived via Ternate-Maluku.

\section{The Establishment of Early Chinese Settlements}

An impressive thing is that Chinese people who come to Indonesia are from one place, but actually they come from various places in China with a variety of characteristics and languages. From the cultural point of view, the presence of Chinese in Manado is called peranakan [descendant] because they have been born, and have grandchildren in Manado, and there is also totok Chinese. For Chinese people from Hokkien, they generally did not come with families and consist of men so they then married native women (Soeryadinata,1988: 2-3).

Of these Chinese descendants, some of them are already in the fourth to the seventh generation. If we count one generation with an average age of 25 years, then if four generation will reach 100 years, and if seven years, then it will be 350 years. Those who are being called descendants, are 
people who have lived a long time, even born in Manado. They are generally descendants who have married and mingled with the local community, they are already called Manado people. This can be proven from the mother tongue used, generally many of them do not know Chinese anymore (Hokkien and Cantonese dialect, Hakka, Kongfu, Ho Chia, and To Chiu, or others) (Soeryadinata, 1984), but their mother language is the Manado Malay, because they already lived together and used everyday social language with the Manado language.

In terms of religion, the Chinese in Manado are mostly Confucians, Buddhists, and Taoists (Tridharma). Interaction with local people takeplace with no denying that there are Chinese people who are Christians, Muslims or others. In the urban areas of Manado, it's hard to say that the Chinese in Manado is a minority. They have mingled with the local population, even in a joke it can be said that they are the local people who are more Chinese than Chinese". This means that sometimes it is difficult to distinguish, which ones are descendants of Chinese and which are not. Things like this are common in urban life, even Chinese people, in general, are in the upper-middle class in social status in the city of Manado.

Judging from its history, Chinese people have long been present through trade routes in this region. The more obvious presence of Chinese in Manado has to do with the construction of the Fort and Niew Amsterdam fortresses. They were brought by the Dutch VOC from Ternate as craftsmen and laborers to assist in building the fort. VOC friendship with the Chinese people had been happened since the early Portuguese and Spanish periods in this region, around the beginning of the 16 th century. Chinese Junks were widely used by VOC for transporting rice from Manado to Ternate (Molsbergen, 1928: 7; Manoppo, 1983: 113).

In its development, when the VOC built the fort in 1655 and was completed in 1703, the workers and workers brought by the VOC from Ternate were Chinese. Along with that, Chinese traders have begun to migrate from Ternate to Wuaua [settlements or villages] of WenangManado, and together with settlement arrangements, they, together with other immigrants, merge to become one east of the Amsterdam fort, and form a village which is now in the pronunciation of the Manado people (still) known as the Chinese Village [Kampung Cina]". As an illustration, the population in the Toar notes (1978: 4) that the population of Minahasa including the population of Manado. In 1821, there were 63,704 inhabitants which consist of 231 were Chinese. Of this number continued to grow in line with the activities of building the fort and (its height) trade route.

Kampung Cina is one of the names of villages in Manado that has special characteristics. they are mobile (active) society. During the colonial government they gathered in a certain place which later formed a society of its own character. Kampung Cina has a role in the development and growth of the city of Manado, both in shaping the character of the city of Manado (houses and old buildings with special characteristics, such as temples and temples and traditions) and especially in the economic sector. Kampung Cina became the embryo of several sports organizations, such as martial arts, which has produced a lot of warriors and masters. Many warriors from around the Indonesian region who come to learn martial arts in Kampung Cina, Manado (Kaunang, 2002: 7). There are several martial art organizations in Manado that were established in Kampung Cina or at the initiative of the Chinese, including Sakura Yudo Kwan College, Yellow Dragon, Golden Dragon, Kao Kun Kanaka, Lo Pa Kong, and Green Dragon.

Recently, the Chinese have remained alive and trying mainly in the field of trade. Since the 19th century, odd trade businesses (mixed) mainly for local commodities from North Sulawesi, especially from Manado and Minahasa, such as intermediary traders for local products, rice, coconut/ copra, coffee and broken goods. Various kinds of expertise that are not owned by local people are controlled by Chinese people, such as laborers, masons, builders, various crafts, etc. Until now, the pioneering efforts of their ancestors are still inherited and attached as part of the identity of Chinese people in Manado (Gunawan, 2013: 45).

Like Chinese settlements, Arabs were also classified as foreign easterners, which by the colonial government was placed in the east next to 
the Kampung Cina. Kampung Arab [Arab village] is close to the Wenang river and not far from the port or the mouth of the Wenang river. The location of the Kampung Arab is directly adjacent to the Kampung Cina, eastern of the fort. Until now the historical position of the settlement is still maintained, it's just that with the development of the expansion of the city and the population, the increasingly narrow the space for people to develop their residential areas.

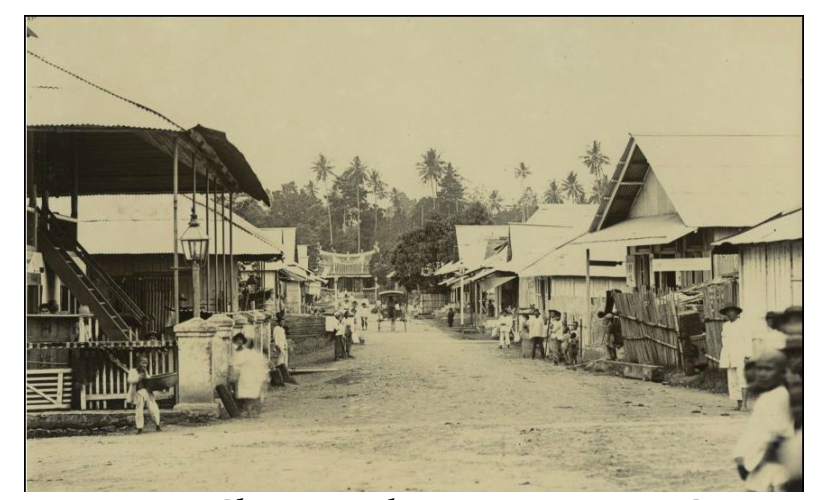

Picture 1. Chinese settlement in Kampung Cina, Manado, 1910.

Source: https://media.kitlv.nl - Albumnumber 1088.

In addition to Ternate people with their Ternate villages, Islamic villages, Kampung Arab, including the later known people of Borgo who settled in Kampung Belanda [Dutch Village] and its surroundings, the settlement of Minahasa people arranged along the road south of the city, southern of the fort. Since the beginning of the formation Manado city as a township, the presence of these villages was part of the historical process that shaped it, starting from the introduction with European foreign nations who conducted trading activities with residents. Active interaction from both parties and the mutual influence of the joints of community life, and the encounter could not be avoided. The offspring produced by the marriage of two different nations, between men and women, both from European men and vice versa with indigenous women produced the Borgo group (Manoppo, 1983: 4, 114), including marriage with Chinese people.

\section{The Establishment of Manado's Pagodas}

In Indonesia, information about the existence of temples began to be established since the 17th century in Batavia in the Glodok region in 1650 (Salmon and Lombard, 1985: 16). The establishment of a pagoda in Manado could not be separated from the presence of Chinese people in Manado. Human attachment and familiarity with his creator and ancestors made Chinese people in various ways to show their respect by building an altar, a prayer house. This can be found in many places in Chinese houses there is an altar table as a place of praying or rituals.

Pagoda is a popular name for a place of worship and for teaching. According to Tjioe (1970: 18-19), the god Hok Tik Tjing Sin is considered the first to have the idea to establish a pagoda. Hok Tik Tjing Sin, by the Hokkian tribe called it Hok Tek Cin Sin or Fu-de Zheng-Shen which in belief is known as the earth god or Thoa Pek Kong. In the city of Manado there are so many pagodas that founded. Some of them were given the nameplate identification of T.I.T.D pagodas or Tri Dharma Pagoda Place: Confucius, Buddhism, and Tao. There is also a pagoda as a place of worship for one teaching, namely khonghucu, such as the Kong Miao Litang Pagoda.

The word pagoda itself became popular in Indonesia where China was not mentioned in its original region, even in Indonesia, when the new order pagoda was equated with the monastery (a Buddhist place of worship) because in the new order most of the tri dharma pagoda joined in one Buddhist sect. In Hakka speaker, the pagoda is called bio. Other names in China are called miao or litang, so that it would be kong miao for Confucians, and gong, guan, and miao for Taoism, then called siyuan, yuan, and an for Buddhism (https://www.tionghoa.info/klenteng/download ed, visited 19 October 2018).

Not far from the location of the Ban Hin Kiong pagoda, in 1839 an ash house (Kong Tek $\mathrm{Su}$ ) was built. At its inception, the pagoda was made from wood, boards interspersed with simple thatched bamboo roofs. This pagoda has been managed since 1935 through an organization of the Sam Khauw Hwee Association. They founded on the efforts and initiatives of two Chinese leaders in Manado, namely Yo Sioe and Que Boen Tjen (Yosadhi, 2005: 26-48).

In the city of Manado itself, there are 14 pagodas have been established. The oldest pagoda 
is the Ban Hin Kiong, which began to exist in 1817 and formalized in 1819 (Yong, 1957). Ban Hin Kiong consists of three words Ban means a lot, Hin means abundant blessing, or kindness, Kiong means palace, so Ban Hin Kiong means a palace of blessing abundant. If observed from outside the gate, the Ban Hin Kiong pagoda is in the form of a "Dragon's head" which is believed that the head is a dragon of the city while the body and tail are circular protecting all the contents of the city (see Picture 2).

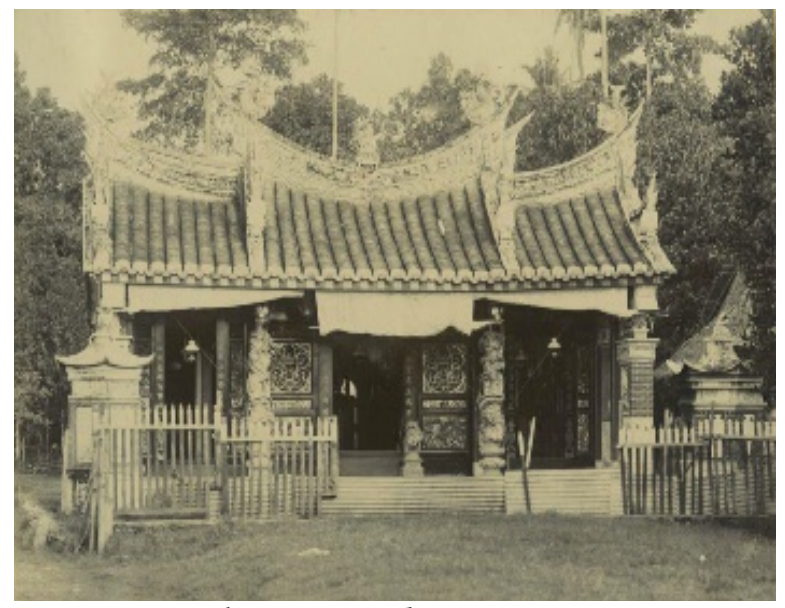

Picture 2. A Chinese Pagoda in Kampung Cina, 1910. Source: https://media.kitlv.nl

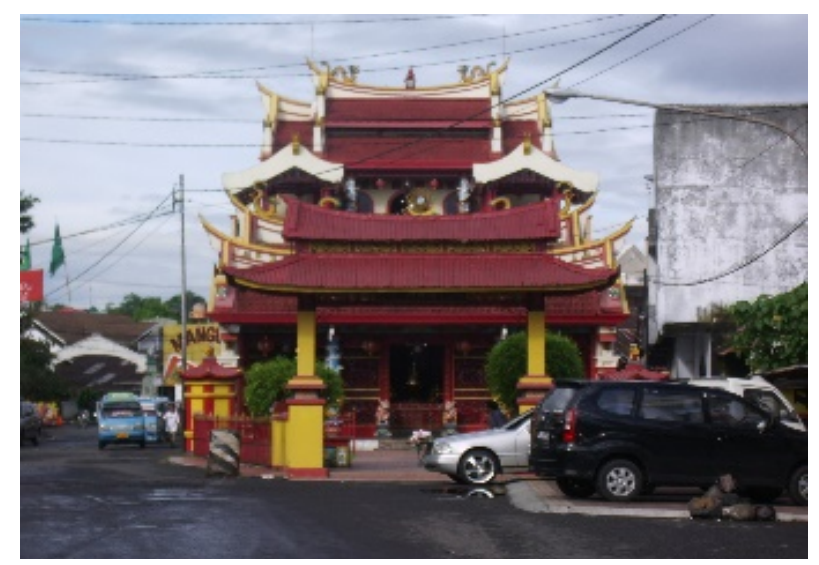

Picture 3. Ban Hin Kiong Pagoda in Manado Kampung Cina.

Source: Author's Documentation, 2006 \& 2007.

On 14th March 1970, the Ban Hin Kiong pagoda was burned on purpose by irresponsible people. At the initiative of Nyong Loho (Soei Swie Goan) who later served as concurrent chair of the construction and chair of the Ban Hin Kiong Pagoda. Then itthe temple began large-scale construction, and renovation. Until now, Ban Hin Kiong Pagoda or commonly abbreviated as BHK has undergone several renovations of the building, both the addition of floors and courtyards as it looks now (Liberty, 1970: 18-19; Gara and Pasiak, 2009: 6-7), please refer to Picture 3. From a historical point of view, the events that took place eliminated many sources, documents and data relating to the lost history of the Ban Hin Kiong Pagoda. Directly, the pagoda archives which have been numbered for years have disappeared, not to mention that the original historical objects imported from China also burned and disappeared.

According to the functional aspect, the temple become a religious and cultural center because it taught several streams of belief and have permanent community. It also functiones as a cultural mean both Confuciansim in particular and Tridharma, in which citizens of Chinese descents acknowledge as a place to learn and develop ancestral culture. It makes Herwiratno (2007) states that pagoda is the last bastion and the starting point for the development of Chinese culture.

As a place of worship, some pagodas of originated from private places of wosrhip. Because of the large number of people who came to pray, it gradually became a place of worship in a large batih family, brothers and sisters, and relatives who began many visitors. From here, there is an element of management or professional management by establishing or joining in a religious organization, such as Buddhism (Walubi), or Confucianism (MAKIN) or Tri Dharma. In general, Manado pagodas bear the name TITD temple or Tridharma place of worship and join the parent organization called the Regional Management TITD North Sulawesi and registered in the Indonesian Buddhism Bimbingan Masyarakat (Binmas) or in the Indonesian Confucius Council (MAKIN) (Interview with Ferry Sondak, September 2019).

Some of the names of pagodas in Manado include (1) Ban Hin Kiong (in Calaca); (2) Kwan Kong (Calaca); (3) Altar Agung (Calaca); (4) Kwan Im Tong (Calaca); (5) Kong Miao Litang (Calaca); (6) Tian Tan Kiong (Calaca); (7) Tiong Tan Lie Goan Swee (Liwas); (8) Kong Tek Tjung Ong (Rike); (9) Lo Tjia Miao (W-wonasa); (10) Hian Thian Siang Tee (Sumompo); (11) Hok Tek Cin Sin (Malendeng); (12) Hok Tek Tjing Sien 
(Teling); (13) Tay Seng Bio (where in Karame already closed); (14) Kwan Seng Bio (Mega Mas).

\section{Development Factors of the Manado's Temples}

Traced on the map of temple locations in the city of Manado, the oldest pagodas were collected and concentrated in the center of the city of Manado, which is now largely located in the government of Calaca. Now only six temples are centered in the Calaca village, namely: 1) Ban Hin Kiong, 2) Kwan Kong; 3) Great Altar; (4) Kwan Im Tong; (5) Kong Miao Litang; (6) Tian Tan Kiong. Other pagodas have been scattered in several places in Manado, some of them were in the Calaca village and have moved to other region, such as the Lo Tjia Miao from Calaca to Wawonasa.

Geographically pagoda in Manado does not have a specific spatial pattern to settle or to be centered in one location as the early establish-ment of the pagoda. In the past, when there were not so many people as now, and only a few pagodas were established, the cultural and religious center of China and the teachings of the Tri Dharma were polarized in one location. It happened also because of historical factors. The new order of Chinese citizens always monitored and polarized somewhere so that it was easy to control. Regarding this, a number of legal products can provide answers to discrimination by the government against this group (Yosadhi, 2012: 57; Yusuf, 2015: 117-119).

According to the informants that the pagoda began to spread in the late 1990s, which had previously been centered around Kampung Cina, the Sub-urb of Calaca, that become economic and trade center. Usually the established temple, will open economic access such as the existence of new shopping centers that can be utilized by residents or surrounding communities. This may have something to do with the Chinese people who does not like to trade or to do whatever business that can carry out life. The ethic work of the Chinese with a joint venture pattern and mutual assistance among them monitored to produce tangible results, holding and being controlled economic ventures and other aspects related to economic activities (Leirissa, 1985: 3637). It gives the city characteristics that will economically developed, let alone the establishment of a temple. Here are some factors that cause the deployment of pagoda in Manado.

\section{Religious}

Religious factors become one of the bases for the temple's deployment in several places in the city of Manado as an answer to people who have the desire to worship or pray who are limited by the distance. On the other hand, teaching of worship and giving impression that worship is not exclusive and merely for the Chinese and their descendants. The temple and teachings are open for public and or other people who want to learn Tri Dharma and follow the teachings or become part of the Dharma's.

\section{Kinship}

This factor is based on the wider social relations of relatives. It includes of the increasing number of people while the pagoda buildings are not increase. It is felt by the community who feel able to establish new places of worship or pagodas by still carrying the "host" of the original pagoda. The host referred to in this case, is the gods or schools, teachings, beliefs that he believes can bring blessings. Like for example, the Lo Tjia pagoda. In Manado there are several winged pagodas / teachings of the god Lo Tjia, so the host of the pagoda is worshiped by the god Lo Tjia.

The host makes pagoda different with others, it referred to the gods and goddesses that become the purpose of worship. Thus, the tridharma people in various pagodas, for the day and time of prayer can be the same. The prayer time conduct to commemorate the birthdays of the gods and goddesses that host it. There are so many gods who become the purpose of prayer, 30 calendar days will never be enough to be a day of prayer, so that the many gods are only chosen and determined the day and time of worship including major holidays, such as Chinese New Year and others.

\section{Economic}

This factor become the most influential because as explained above, in general Chinese people are engaged in economic and trade business. From here, they establish and run business claims or a 
joint venture to prosper (prosperous) together. Some of their income is donated for pagoda's construction or worship activities, ceremonies, commemoration of holy days and other rituals.

\section{Other Factors}

Chinese citizens and their descendants are increasing, assimilation of citizenship with local residents in the surrounding environment often occurs. Many marriages between Chinese descendants and local residents occur, including in Manado (Goni, 1985). The existence of an intense relationship without distinguishing one from another, Chinese or not Chinese, the marriagemawin is inevitable and some of them locals adhere to the teachings of Confucianism or join Tridharma. On the contrary, there are many Chinese citizens and their descendants who at first had embraced religion and other beliefs, such as Islamic Chinese. Sometimes, for some people form their own partnership feel able to establish their own pagoda by calling acquainttances, associations, business friends, relatives of extended family, to become member in the pagoda he founded.

\section{The Impact of Pagoda Deployment in Manado}

The major of old cities and port cities are arranged by the colonial government in accordance with the segregation of colonial urban settlement structures. As a colonial city, there are fortresses or former colonial fortresses, pakhuis or lodge warehouses, houses with colonial-style, and spatial spaces for indigenous people and other Asian settlers. For example, Chinese in Manado lives at Kampung Cina.

There are facilities for the needs of the Chinese such as temples and ash houses. The oldest pagoda in the city of Manado is located in Kampung Cina which is now included in the Calaca village administration. The impact of the existence of a pagoda in a location gives the Chinese people the central attraction to live and settle in the vicinity of the pagoda. Although in its development today, there is no longer strong assumption that pagodas are centered in the Kampung Cina. Nowadays, the pagodas have been built, deployed both on the edges and in the large city spaces. Here are some of the effects of the pagoda deployment in the city of Manado.

\section{The City Spatial Space in Diversity of Religion}

The rapid growth and population density can cause urban spatial to no longer adequately accommodate the economic activities of the population and the land use. It is felt that sacred spaces are agitated by the socio-economic activities of a dense urban community. This is also one of the reasons for the pagoda deployment to the edges of Manado or in city spaces that had not been maximally utilized.

Pagoda as one of the houses of worship functions to carry out religious activities with freedom to express their beliefs. Devotion in worship is greatly missed by every devotee in worship and become no exception only to the Confucianist or Tridharma people in relation to the pagoda.

Meanwhile, nowadays the temple is no longer concentrated in the city center or near with the economic center. Instead, they were started to be built in coastal suburbs area.

Land-use of the city becomes evident when several temples are built in spatial spaces which, if observed in a frog jump pattern, are spread out without a specific pattern. There are pagodas built on the outskirts of the city, in quiet locations. However, there are pagodas built in the midst of densely populated settlements and still rarely found any large buildings, such as pagoda buildings. Specifically, pagoda is built on the outskirts of the city, this has the effect of opening up access to suburban spaces with inner-city spaces. The accessibility of this space has an impact on the wide opening of new economic spaces. It is due to on an assumption that the construction site of new worship houses, including pagoda, should provide open space or for economic business opportunities. It arises many developers and housing contractors who then take advantage of this assumption.

The establishment of a pagoda building interspersed with local residents. The diversity of religions and beliefs provide harmony in the spatial diversity of worship places in Manado. It has positive impact for residents to be survived. Manado referred as a tolerant city, a city that knows 
to respect the right of each people to live side by side in the same urban space that they love.

\section{Chinese Business and Trade from Outside}

There is not much quantitative evidence or recorded statistics on how many Chinese entrepreneurs from regions outside Sulawesi open new businesses and trade in Manado. Even so, it is undeniable that the presence of Chinese people engaged in business and commerce is in significant numbers.

One sign of the Manado's Chinese existence is the construction of the Kwan Seng Bio Pagoda which stands in the Megamas reclamation area of Manado. This pagoda stands in the middle of the largest business district in the city. According to several informants, this pagoda was established to provide comfort to Chinese citizens from outside to carry out their religious obligations. This pagoda was built as a form of acceptance to fellow the Chinese by creating healthy socio-economic relations in running a business in Manado.

\section{A City Symbol: Harmony, Safety, and Peace}

Manado known as city with thousand churches and has been called as New Jerusalem. Both of two impressions are given by outsiders. By giving such opinions, the direct or indirect marginalized religious communities have existed for a long time in this area, but they can live in harmony and peace with one another. This objective condition negating other religions and beliefs in the city. As a nation that lives within the framework of the NKRI, there is no such thing as a majority or minority. All religions and beliefs, classes and backgrounds, ethnic identity have simliar rights and obligations as long as they are Indonesian citizen. However, the construction site of temples show that this area does not have mutual suspicion, there is no minority and majority, there is no partition between the nation's children.

The construction of temples in several places has actually raised the reality that the community is open, grown-up and together consciously creates harmonization of living side by side with the goal of safe, peaceful and prosperous. History has indeed recorded an interest conflict between religious communities in this area that intersects with Chinese even to the burning of the
Ban Hin Kiong pagoda in 1974. However, from that history this area learned to organize a life together among religious people.

The establishment of the Interfaith Religious Cooperation Agency (BKSUA) is to answer the gloomy challenges of history in relations between religious communities. In fact, many areas make Manado become one of destinations for comparative studies and research about living in harmony and peace among the faithful in the city. Not only that, from this area cities in Indonesia imitated and became the same pattern of establishing the same organization in their area with the existence of BKSUA throughout Indonesia (Kaunang in Margana, et al. 2017: 188). Manado is one of the pioneering cities that provides an example of harmonious life between religious believers in Indonesia.

\section{House of Worship Contestation and Seizure of Sacred Spaces}

The construction of houses of worship in Manado gets the impression that there has been a contestation over the sacred space. Makelo's (2010) research on this matter, although only limited to one or two denominations but has increasingly felt also with the presence of pagodas in many places which no longer centralized in a central business location.

The contest for worship houses is likened to highlighting the beauty, grandeur of the building rather than highlighting the quality of worship. Likewise, the struggle for the sacred space is the struggle for strategic locations to build worship houses of various denominations and teachings. The construction site of worship houses penetrates into certain hills and mountains that contour the land topography. While the construction is on progress, it has been very clearly seen the houses can attract the people's interests to visit or to worships.

\section{Increasing Tourism Destinations and Employments}

It is undeniably eventhough religious tourism is interesting, but in the case of Manado, this type of tourism has not been managed well. In particular, for pagodas without being used as one of the destinations, because the shape and variety of 
decoration and the symbols of the temple are unique and distinctive, then the interest of domestic and foreign tourists to visit, traveling to the pagoda is increasingly widespread.

By tourism and the rapid advancement of tourist visits directly open new jobs in various aspects of the business. The home industry in providing souvenirs is one of the challenges of new jobs. A tour guide with good command of Mandarin provides new job opportunities and good to attract impression from Chinese tourist. On a small scale, the velocity of money provides the density of transportations, hotel and lodging occupancies, small and medium businesses. Other businesses engaged in tourism also enrich new jobs, such as the travel agent business and other services (barber shops, reflexology, publication business, parking lots, etc). Thus, sectors are promising and contributes for developing pagodas.

\section{Conclusion}

The deployment of pagoda in Manado cannot be separated from the life of the local community who respect each other and open themselves in social relationships, social interactions and culture in many aspects of life. It is true that friction and conflict between religious believers has occurred in this area and directly intersect with the Chinese, but that later becomes a lesson learn. It also increasingly giving space to the relationship between religious believers to create harmony among religious believers in Manado. As a tolerance city, it proving the quality of human life in the city of Manado.

The oldest pagoda in Manado is named Ban Hin Kiong, which was founded in 1817 and inaugurated in 1819. The distribution of pagodas in many places began in the late 1990s, starting in the city center, trade and business centers, then expand in various areas. Now, it has opened wider economic access. The linkage of the road network with the city center is created to provide wide opportunities for the occupancy by utilizing public spaces.

There several factors of pagoda deploy-ment in the Manado, it involves religious, kinship, economic, and other factors. Likewise, the impact of the pagoda in Manado has resulted in the opening of the city's spatial space in diversity. Furthermore, the establishment of pagodas is to provide space for migration of people from outside Manado to do business in this tolerant city, the creation of a peaceful and harmonious community, as a picture of harmony. Th distribution of pagodas also had an impact on fighting over worship places and sacred spaces. On the other hand, it added new tourism destinations and opened up employment opportunities.

\section{References}

“Pasiar Tapikong (Tjap Go Meh).” Fikiran, No. 9, 5 Maret 1927.

"Sekelumit Riwayat Klenteng Ban Hin Kiong di Menado." Majalah Liberty, No. 874. 6 Juni 1970: 19-22.

Brouwer. M. (1936). Bestuurstelsel en Bestuurvormen in de Minahasa. Harlem: $\mathrm{H}$. Voenman \& Zonen-Wageningen.

de Graaf, S. (1918). Encyclopaedia van Nederlandsch Indie, Deel II. Leiden: Martinus Nijhoff S'Gravenhage.

Gara, N. and Pasiakh, T. (2009). Agama-Agama Pemanasan Global dan World Conference. Sulut: FKUB.

Goni, Jhon Hein. (1985). "Studi Perkawinan Campuran pada Masyarakat Cina di Manado.” Ph.D. Dissertation at Universitas Gadjah Mada.

Gunawan, H. (2013). Yok Chae dan Chung Hwa: Menelusuri Jejak-jejak Komunitas Tionghoa di Manado. Yogyakarta: Kanisius.

Herwiratno. M. (2007). “Kelenteng: Benteng Terakhir dan Titik Awal Perkembangan Kebudayaan Tionghoa di Indonesia." Jurnal Lingua Cultura, Vol.1 (1): 78-86.

https://www.tionghoa.info/klenteng/, retrieved 19 Oktober 2018).

Kaunang, I. R. B. (2017). "Sejarah Keragaman dan Keberagamaan di Kota Manado", S. Margana, A. Faisol, A. Handayani (Ed.). Pluralisme dan Identitas, Pengalaman dan Pandangan Berkebangsaan. Yogyakarta: Ombak.

Kaunang, I. R. B., Haliadi., L. O. Rabani. 2016. Jaringan Maritim Indonesia: Sejarah Toponim Kota Pantai di Sulawesi. Jakarta: 
Direktorat Sejarah, Direktorat Jenderal Kebudayaan, Kementerian Pendidikan dan Kebudayaan.

Kaunang, Ivan R. B. (2002). "Kampung Cina di Manado.” Harian Komentar, Manado: 11 Februari. hlm 7.

Leirissa, R. Z. (1985). Terwujudnya Satu Gagasan: Sejarah Masyarakat Indonesia, 1900- 1950. Jakarta: Akademika Pressindo.

Makelo, I. D. (2010). Kota Seribu Gereja: Dinamika Keagamaan dan Penggunaan Ruang di Kota Manado. Yogyakarta: Ombak.

Manoppo-Watupongoh, Y. J. (1983). "Bahasa Melayu Surat Kabar di Minahasa pada Abad ke-19.” Ph.D. Dissertation at Universitas Indonesia.

Molsbergen, E. C. G. (1928). Geschiedennis van de Minahasa tot 1879. LamdsdruikerijWeltevreden.

Salmon, C. 1. and Lombard, D. (1985). KlentengKlenteng Masyarakat Tionghoa di Jakarta Jakarta: Yayasan Cipta Loka Caraka.

Soeryadinata, L. (1984). Dilema Komunitas Tionghoa. Jakarta: Grafitty Press.

Soeryadinata, Leo. (1988.) Kebudayaan Minoritas Tionghoa di Indonesia. Jakarta: Gramedia Pustaka Utama.

Staatsblad, 24 Juni 1824.

Tjioe (1970). "Hok Tik Tjing Sin atau Pepunden Pemelihara Dharma Selamat.” Tjahaja TriDharma No. 10 Tahun ke-I.

Toar. D. (1978). “Orang Cina di Manado.” Tesis Department of History Universitas Sam Ratulangi.

Tong-Pao, No. 1. Tahun 1. 10 November 1927.

Wulanningrum, S. D. (2018). "Makna Ragam Hias pada Fasad Bangunan (Studi Kasus: Kelenteng Ban Hin Kiong, Manado).” Jurnal Muara Ilmu Sosial, Humaniora dan Seni, Vol. 2 (2): 563-574.

Yong, O. P. (1957). Berdirinya Rumah Toapekong, Kongteksoe dan Tjeng Beng serta Riwajat Tangsien (Tangtjkie dan Perkumpulan Hap Tan dengan Urusan Sembahjang jang ada Terikat Dalamnya, serta Adanya Perkumpulan Sam Kauw Hwee di Manado. Manado: Pertjetakan Menado.
Yosadhi, S. (2005). "Sekilas tentang Perkembangan Agama Khonghucu di Manado dan sekitarnya”. Kenangan Perayaan Hari Lahir Nabi Khonghucu 2556. Surabaya: Majelis Agama Khonghucu Indonesia (MAKIN): 26-48.

Yusuf, I. A. (2005). Media Kematian dan Identitas Budaya Tionghoa. Jakarta: UII Press.

\section{Informant}

Ferry Sondak, September 2019. 